Journal of Clinical Investigation

Vol. 42, No. 2, 1963

\title{
EFFECT OF ACUTE METABOLIC ACIDOSIS AND ALKALOSIS ON ACETATE AND CITRATE METABOLISM IN THE $\mathrm{RAT}^{*}$
}

\author{
By EDWIN E. GORDON † \\ (From the Department of Medicine, Albert Einstein College of Medicine, Yeshiva University, \\ and the Bronx Municipal Hospital Center, New York, N. Y.)
}

(Submitted for publication July 23, 1962; accepted October 10, 1962)

An enhanced urinary excretion of citrate after administration of alkali and a diminished citrate excretion after administration of ammonium chloride were first observed by Östberg in 1931 (1). More recently, it has been pointed out that the quantity of citrate excreted in the urine is not a direct consequence of acidification or alkalinization of the urine as believed by Östberg, but rather is related to systemic $\mathrm{pH}(2)$. Hypercitraturia is associated with alkalosis and hypocitraturia with acidosis. This correlation appears to be independent of the mechanism of production of the altered acid-base balance. Thus, urinary citrate is diminished in diabetic acidosis $(1,3,4)$, as a result of the intracellular acidosis of potassium depletion $(5,6)$, and in the metabolic acidosis induced by acetazolamide $(2,7,8)$, as well as by administration of $\mathrm{NH}_{4} \mathrm{Cl}, \mathrm{CaCl}_{2}$, and $\mathrm{HCl}$. Increased excretion of citrate in the urine has been observed during respiratory alkalosis $(4,6,9)$ as well as during metabolic alkalosis.

Two hypotheses have been proposed to explain this effect of altered acid-base balance on urinary citrate excretion. One hypothesis holds that alterations of $\mathrm{pH}$ influence the synthesis of citrate and its subsequent secretion by renal tubules (10). This implies that the intracellular $\mathrm{pH}$ of the renal tubular cell influences substrate metabolism in the Krebs citric acid cycle with subsequent transport of metabolites from the renal cell into the tubular urine. The second hypothesis, based on data obtained by conventional clearance techniques $(11,12)$, suggests that acidosis results in

* Work supported by research grant A-2598 from the National Institutes of Health, U. S. Public Health Service; presented in part at the April, 1962, meeting of the Federation of American Societies for Experimental Biology, Atlantic City, N. J.

$\dagger$ Investigator of the Health Research Council of the City of New York under contract I-156. an increased renal tubular reabsorption of citrate and alkalosis in a decreased tubular reabsorption of filtered citrate. This would implicate membrane transport as a major mechanism affected by $\mathrm{pH}$ changes.

It has previously been shown in this laboratory that the urinary citrate is at least in part derived from the blood citrate, since an appreciable portion of intravenously administered citrate- $\mathrm{C}^{14}$ appears unchanged in the urine (13). In the present investigations, a similar experimental approach employing radioactive tracer substances was used to study the mechanism by which acute alterations of acid-base balance influence urinary citrate excretion. These experiments support the second hypothesis, namely, that there is a $\mathrm{pH}$ effect on renal tubular reabsorption of filtered citrate. In addition, they provide information bearing on the origin and metabolic fate of the blood citrate in alkalosis and acidosis.

\section{MATERIALS AND METHODS}

Fed, female, Sprague-Dawley rats weighing approximately $200 \mathrm{~g}$ were used. $\mathrm{HCl}$ or $\mathrm{Na}_{2} \mathrm{CO}_{3}, 1.5$ mmoles, was administered intragastrically in a volume of $3 \mathrm{ml}$; control animals received $3 \mathrm{ml}$ of water. In all experiments, $0.3 \mathrm{ml}$ of the radioactive compound was injected intravenously as a neutral solution in isotonic saline 30 minutes after administration of the test solution. Animals were restrained in wire cages, and precautions were taken to separate urine and feces during the 3-hour collection period. At the appropriate times, the animals were encouraged to empty their bladders by painful stimulation. The urine and washings were filtered and made up to volume before assay for $C^{14}$ in urine, in urinary citrate, and for total citrate content. At the end of the collection period, the rats were anesthetized with ether, and blood was drawn from the abdominal aorta for determination of citrate concentration.

The $\mathrm{pH}$ of mixed tail blood was determined with a Radiometer pHM 4 meter and Astrup micro blood glass electrode. The citric acid-1,5- $\mathrm{C}^{\mathbf{1 4}}$ was obtained from 
Tracerlab, Inc., and $\mathrm{Na}$ acetate-1- $\mathrm{C}^{\mathbf{1 4}}$ from the New England Nuclear Corp.

The radioactivity of the urine and of the urinary citrate was determined by methods previously described with appropriate corrections for self-absorption and conversion of values to infinite thickness (13). Quantitative analysis of blood and urinary citrate was performed as previously described, by the technique of Elliott (14). For the determination of the specific radioactivity of the plasma citrate, the cells were separated from heparinized blood and the plasma proteins were precipitated by heating at acid $\mathrm{pH}$; the supernatant solution was then subjected to ion-exchange chromatography on a Dowex-2 column in the formate form (15). The column eluate containing the organic acids was dried under reduced pressure at $40^{\circ} \mathrm{C}$. An aqueous solution of the organic acids was prepared, and a sample was subjected to ascending paper chromatography on Whatman no. 1 paper in the II solvent system of Hartley and Lawson (16). Citric acid was then eluted from the paper, and samples were taken for plating and counting at infinite thinness in a Nuclear-Chicago gas-flow counter with Micromil window, and for citric acid analysis.

\section{RESULTS}

Effect of alkalosis and acidosis on fate of i.v.administered citrate- $C^{14}$. Intubation of the rat's stomach with a special needle ${ }^{1}$ could usually be

1 No. 71-042, Phipps and Bird, Inc. accomplished in less than half a minute. Despite the ease and rapidity of the procedure, the $\mathrm{pH}$ of the blood fell as much as $0.1 \mathrm{U}$ within 5 minutes regardless of the $\mathrm{pH}$ of the fluid administered (Figure 1). The blood $\mathrm{pH}$ subsequently rose to control levels in the animals that received water, to levels significantly above the control value in those that received alkali, and continued to fall during the observation period in the animals that received acid. There was a slightly greater and more prolonged elevation of the blood $\mathrm{pH}$ after 3 $\mathrm{ml}$ of $1.0 \mathrm{M} \mathrm{Na}_{2} \mathrm{CO}_{3}$ compared to that seen after $3 \mathrm{ml}$ of $0.5 \mathrm{M} \mathrm{Na}_{2} \mathrm{CO}_{3}$.

The citrate concentration of the blood was unaltered by alkali or acid administration (Table I). Examination of the blood citrate concentration at 30 and at 60 minutes after administration of the test solution indicated that the values did not differ significantly among control, alkalotic, and acidotic rats. After 30 minutes the values were $31.8 \pm 1.6,31.0 \pm 0.6$, and $27.1 \pm 1.0 \mu \mathrm{g}$ per $\mathrm{ml}$, and after 60 minutes they were $29.4 \pm 1.8,28.3 \pm$ 1.3 , and $27.1 \pm 1.6 \mu \mathrm{g}$ per $\mathrm{ml}$ for control, alkalotic, and acidotic rats, respectively. Urinary citrate increased in the alkalotic and decreased in the acidotic rat $(p<.001$, control against each

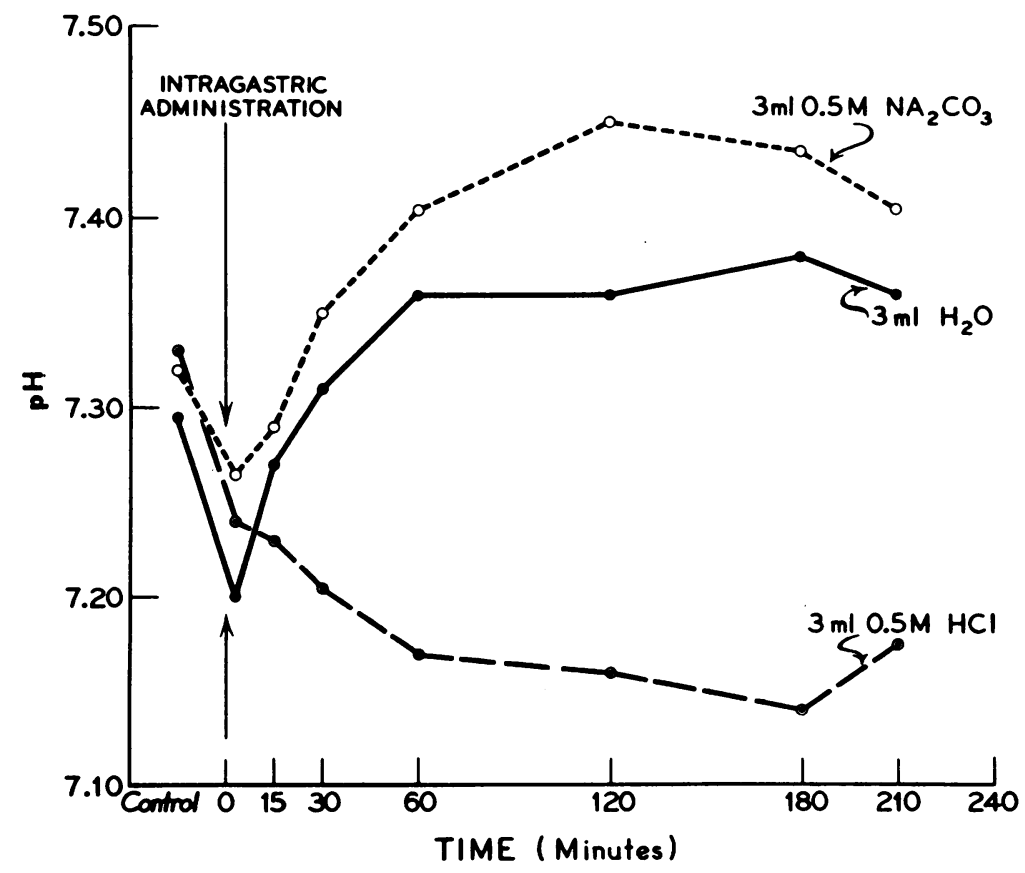

Fig. 1. Blood pH after intragastric administration of Water, AlKali, AND ACID. Values for each treatment are the means of 3 rats. 
TABLE I

Citrate concentration in blood and urine of normal, acidotic, and alkalotic rats *

\begin{tabular}{lccc}
\hline \hline & Acidotic & Control & Alkalotic \\
\hline Blood citrate, $\mu \mathrm{g} / \mathrm{ml}$ & $\begin{array}{c}25.0 \pm 1.6 \\
{[10]}\end{array}$ & $\begin{array}{c}28.3 \pm 0.9 \\
{[7]}\end{array}$ & $\begin{array}{c}27.4 \pm 0.9 \\
{[13]}\end{array}$ \\
Crine citrate, $\mathrm{mg} / 3$ hours & $\begin{array}{c}0.49 \pm 0.15 \\
{[10]}\end{array}$ & $\begin{array}{c}5.33 \pm 0.42 \\
{[10]}\end{array}$ & $\begin{array}{c}10.31 \pm 0.47 \\
{[10]}\end{array}$
\end{tabular}

* Values are the means \pm standard error of the number of experi ments indicated in brackets.

experimental group). The urine collected during the 3 hours after intravenous injection of $4 \mu \mathrm{g}$ citrate- $C^{14}\left(1.1 \times 10^{5} \mathrm{cpm}\right)$ contained approximately 30 per cent of the administered $\mathrm{C}^{14}$ in control, 65 per cent in alkalotic, and 5 per cent in acidotic rats (Figure 2). Further analysis indicated that almost all of the $\mathrm{C}^{14}$ in the urine was present in the carboxyl groups of the urinary citrate. That is, the administered citrate was excreted in the urine unchanged, since the urinary citrate was labeled in the same positions as the administered radioactive citrate.

In other experiments, twice as much $\mathrm{Na}_{2} \mathrm{CO}_{3}$ (3.0 mmoles per rat) was administered. The values for blood citrate concentration, urinary citrate concentration, and percentage of counts in the urine and urinary citrate were indistinguishable from those seen after administration of 1.5 mmoles per rat.

A study of the rate of urinary excretion of injected citrate- $\mathrm{C}^{14}$ in control and alkalotic rats clearly indicated the rapidity with which the kid-

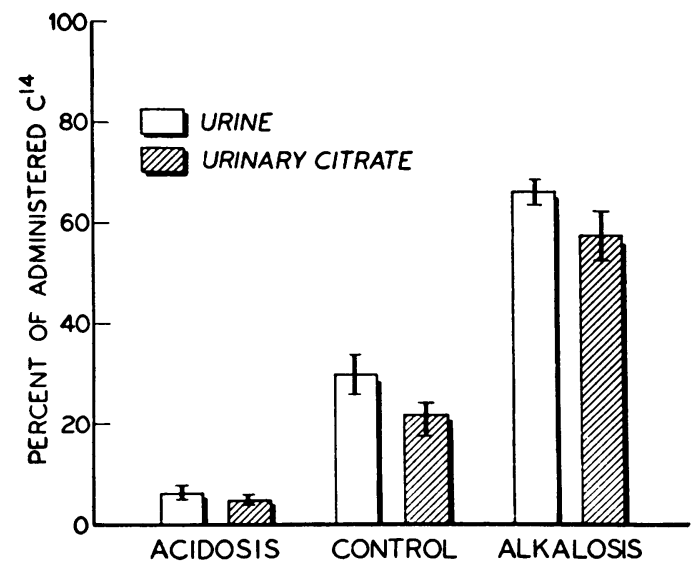

Fig. 2. Urinary $C^{14}$ after administration of CITRATE-C ${ }^{14}$ TO CONTROL, ACIDOTIC, AND ALKALOTIC RATS. Values are the means of 5 rats \pm standard error.
TABLE II

Rate of $C^{14}$ appearance in urinary citrate of control and alkalotic rats after i.v. citrate-C $C^{14} *$

\begin{tabular}{ccc}
\hline Time & Control & Alkalotict \\
\hline $\min$ & & \\
$0-30$ & 0.58 & 0.62 \\
$30-60$ & 0.18 & 0.20 \\
$60-120$ & 0.14 & 0.14 \\
$120-180$ & 0.09 & 0.04 \\
Total (3 hours) & 1.00 & 1.00
\end{tabular}

* The value for each period is expressed as a fraction of the total citrate- $\mathrm{C}^{14}$ excreted in the urine during the 3-hour collection period. Three rats were used in each series.

$\dagger 1.5$ mmoles $\mathrm{Na}_{2} \mathrm{CO}_{3}$ intragastrically 30 minutes before injection of citrate-C ${ }^{14}$.

ney cleared the labeled plasma citrate (Table II). Of the total citrate- $\mathrm{C}^{14}$ excreted in the urine, more than half had appeared within 30 minutes and approximately three fourths had been cleared by the kidneys in the first hour in both groups of animals.

Effect of alkalosis and acidosis on jate of i.v.administered acetate- $C^{14}$. Approximately 1 to 1.5 per cent of the $\mathrm{C}^{14}$ of $34 \mu \mathrm{g}$ of intravenously administered $\mathrm{Na}$ acetate-1-C ${ }^{14}\left(7 \times 10^{6} \mathrm{cpm}\right)$ was found in the urine of control animals during the 3 -hour collection. In alkalotic rats about 5 per cent, and in acidotic rats about 0.2 per cent of the $\mathrm{C}^{14}$ was recovered in the urine (Figure 3 ). Despite the relatively small recoveries of $\mathrm{C}^{14}$ in the urine after acetate-C $\mathrm{C}^{\mathbf{1 4}}$ injection, the values for the experimental groups were significantly different from those of the control group ( $p<.001)$. Most of the radioactivity in the urine of alkalotic ani-

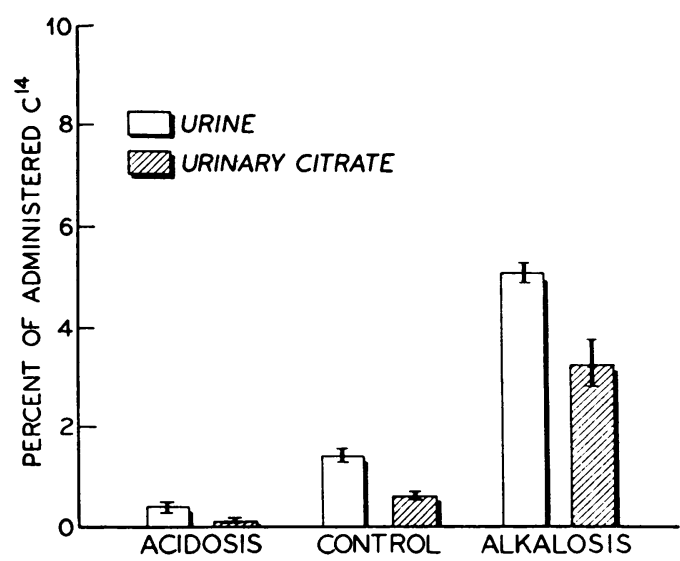

Fig. 3. Urinary $\mathrm{C}^{14}$ after administration of ACETATE-C ${ }^{14}$ TO CONTROL, ACIDOTIC, AND ALKALOTIC RATS. Values are the means of 5 rats \pm standard error. 
TABLE III

Rate of $C^{14}$ appearance in urinary citrate of control and alkalotic rats after $i . v$. acetate- $C^{14} *$

\begin{tabular}{ccc}
\hline \hline Time & Control & Alkalotict \\
\hline $\min$ & & \\
$0-30$ & 0.58 & 0.26 \\
$30-60$ & 0.18 & 0.28 \\
$60-120$ & 0.14 & 0.31 \\
$120-180$ & 0.09 & 0.15 \\
Total (3 hours) & 1.00 & 1.00
\end{tabular}

* The value for each period is expressed as a fraction of the total citrate- ${ }^{14}$ excreted in the urine during the 3-hour collection period. Three rats were used in each series.

$\dagger 1.5$ mmoles $\mathrm{Na}_{2} \mathrm{CO}_{3}$ i.g. 30 minutes before injection of acetate- $\mathrm{C}^{14}$.

mals was present in the urinary citrate; no attempt was made to assay the $\mathrm{C}^{14}$ content of urinary constituents other than citrate, but it seems likely that the undefined compounds containing the radioactivity were other organic intermediates or bicarbonate.

Administration of acetate- $\mathrm{C}^{14}$ to rats that had received twice as much alkali ( 3 mmoles per rat) resulted in essentially the same findings as those seen after the smaller amount.

The rate of acetate- $\mathrm{C}^{14}$ incorporation into the urinary citrate of control and alkalotic rats is indicated in Table III. The rate of appearance of the $\mathrm{C}^{14}$ into urinary citrate in control rats is the same as that seen after intravenous citrate- $\mathrm{C}^{14}$ administration. That is, of the total urinary citrate$\mathrm{C}^{14}$ in the 3-hour collection period, more than one half is excreted in 30 minutes. In alkalotic rats, however, the rate of appearance was delayed. $\mathrm{Ci}$ trate- $\mathrm{C}^{14}$ continued to appear in the urine in appreciable amounts throughout the collection period. These data provide evidence for a continuous synthesis of plasma and urine citrate; release of citrate from pools, such as are known to be present in bone (17), has not been ruled out.

Effect of alkalosis on synthesis of blood citrate in nephrectomized rats. In the nephrectomized preparation, a major organ of utilization and of

TABLE IV

Incorporation of acetate-1-C 14 into the plasma citrate of nephrectomized rats

\begin{tabular}{lcc}
\hline \hline & Control (5 Rats) & Alkalotic (4 Rats) \\
\hline Plasma citrate, $\mu \mathrm{g} / \mathrm{ml}$ & $196 \pm 18$ & $194 \pm 15$ \\
Specific activity, cpm/ $\mu \mathrm{g}$ & $16.2 \pm 2.8$ & $18.7 \pm 2.9$ \\
\hline
\end{tabular}

excretion of the plasma citrate is eliminated. Under these conditions, an effect of alkali administration on synthesis and release of citrate from extrarenal tissue would be accentuated. The values for blood citrate concentration and the specific activity of the plasma citrate 2.5 hours after oral administration of the test substance ( 3.5 hours after nephrectomy) and 30 minutes after $60 \mu \mathrm{c}$ of $\mathrm{Na}$ acetate- $\mathrm{C}^{\mathbf{1 4}}(200 \mu \mathrm{c}$ per $\mathrm{mg})$ are seen in Table IV. Although these data confirm the previous observations of blood citrate elevations in nephrectomized rats (18), they fail to reveal any difference between the nephrectomized rats that received water and those that received alkali. Neither the blood citrate concentration nor the specific activity of the plasma citrate differed in the two groups of animals. It therefore seems unlikely that acute alkali administration results in a significant extrarenal citrate synthesis or release.

\section{DISCUSSION}

The key role of citrate in the metabolic pathway leading to energy production, and the dramatic changes in urinary citrate excretion in acidosis and alkalosis naturally lead one to associate these events. The hypothesis that citrate metabolism in the renal tubular cell is closely related to urinary citrate excretion is particularly attractive because of the known avidity of the kidney for the blood citrate $(19,20)$ and because of the demonstrated rapid metabolism of citrate by kidney tissue (13). The present experiments conclusively demonstrate an effect of acidosis and alkalosis on renal clearance of plasma citrate. The data are consistent with the view that alkalosis results in a decreased tubular reabsorption of filtered citrate and acidosis in an increased tubular reabsorption of filtered citrate. These conclusions agree with interpretations based on conventional clearance methods $(11,12)$ and on stop-flow analysis (21). An effect of acute alterations of acid-base balance on tubular secretion of plasma citrate has not been ruled out.

It has been suggested (10) that alterations of $\mathrm{pH}$ influences synthesis and subsequent secretion of citrate by the renal tubules. Although hypercitraturia has been shown to occur in association with an increased citrate concentration in kidney tissue in such diverse conditions as alkalosis (22), 
after sodium malate administration (23), and in fluorocitrate-poisoned rats (13), the increased urinary excretion need not be a consequence of the increased tissue concentration $(13,24)$. The data obtained in the present study suggest that tubular synthesis of citrate is not a major determinant of citrate excretion in the urine.

When acetate- $\mathrm{C}^{14}$, a metabolic precursor of citrate, was administered, an increased incorporation of the $\mathrm{C}^{14}$ into urinary citrate was observed in alkalosis and a decreased incorporation in acidosis. The most likely interpretation of these data is an increased renal clearance of plasma citrate that had been labeled with $\mathrm{C}^{14}$ by condensation of the acetate- $\mathrm{C}^{14}$ with oxaloacetate in tissues. It is clear that labeled acetate is incorporated into plasma citrate (Table IV), and that this radioactively labeled citrate would be excreted by the kidneys in accordance with the demonstrated effect of $\mathrm{pH}$ alterations on the renal clearance of plasma citrate. It is of interest that tubular secretion of malate, another member of the tricarboxylic acid cycle, has been demonstrated $(25,26)$; alterations of acid-base balance do not appear to influence the urinary excretion of this intermediate (4).

The present studies have demonstrated an increased renal clearance of plasma citrate in the alkalotic rat without diminution of the concentration of citrate in the plasma. This finding suggests two possibilities, increased release of citrate into the blood, and decreased uptake and metabolism of plasma citrate by the tissues. The first appears to be remote in view of the present inability to demonstrate an increased incorporation of acetate- $\mathrm{C}^{14}$ into plasma citrate of alkalotic nephrectomized rats. The second possibility, diminished metabolism of blood citrate in the alkalotic rat, is supported by experiments with citrate- $\mathrm{C}^{14}$. In the normal animal, approximately 55 per cent of an administered dose of citrate- $\mathrm{C}^{14}$ is found in the respiratory $\mathrm{CO}_{2}$ in 3 hours (13). In the alkalotic animal, only 35 per cent at most could be metabolized, since 65 per cent of the administered citrate- $\mathrm{C}^{\mathbf{1 4}}$ is excreted in the urine. In agreement with this hypothesis, Mårtensson (19) has provided data which suggest that metabolism of citrate by the kidneys increases in acidosis and decreases in alkalosis. Preliminary experiments in this laboratory indicate that citrate metabolism by rat kidney slices is greater when they are incubated at $\mathrm{pH} 6.5$ then at physiological or slightly alkaline $\mathrm{pH}(27)$. Clarification of this relationship between effects of altered $\mathrm{pH}$ on intracellular citrate metabolism and tubular reabsorption of citrate must await further experimentation.

\section{SUM MARY}

The mechanism of the altered urinary citrate excretion in acute metabolic alkalosis and in acute metabolic acidosis was studied in rats. Systemic $\mathrm{pH}$ influences the renal clearance of plasma citrate- $\mathrm{C}^{14}$. The data are consistent with the mechanism of increased tubular reabsorption of filtered citrate in acidosis and decreased tubular reabsorption of filtered citrate in alkalosis.

Data have been presented which suggest that there is a continuous synthesis and release of citrate from extrarenal tissues, and that alkali administration does not influence this process.

The evidence for a relationship between citrate metabolism by the kidney and citrate excretion in the urine, under conditions of altered acid-base balance, has been summarized.

\section{ACKNOWLEDGMENT}

The skillful technical assistance of Mrs. Gyda Weinstein is gratefully acknowledged.

\section{REFERENCES}

1. Östberg, O. Studien über die Zitronensäureausscheidung der Menschenniere in normalen und pathologischen Zuständen. Skand. Arch. Physiol. 1931, $62,81$.

2. Clarke, E., Evans, B. M., MacIntyre, I., and Milne, M. D. Acidosis in experimental electrolyte depletion. Clin. Sci. 1955, 14, 421.

3. Boothby, W. M., and Adams, M. The occurrence of citric acid in urine and body fluids. Amer. J. Physiol. 1934, 107, 471.

4. Gamble, W., Orten, J. M., and Smith, A. H. Citric acid cycle in certain alterations of acid-base balance in human subjects. J. appl. Physiol. 1961, 16. 593.

5. Fourman, P., and Robinson, J. R. Diminished urinary excretion of citrate during deficiencies of potassium in man. Lancet 1953, 2, 656.

6. Evans, B. M., MacIntyre, I., Macpherson, C. R., and Milne, M. D. Alkalosis in sodium and potassium depletion (with especial reference to organic acid excretion). Clin. Sci. 1957, 16, 53.

7. Harrison, H. E., and Harrison, H. C. Inhibition of urine citrate excretion and the production of re- 
nal calcinosis in the rat by acetazoleamide (Diamox) administration. J. clin. Invest. 1955, 34, 1662.

8. Gordon, E. E., and Sheps, S. G. Effect of acetazolamide on citrate excretion and formation of renal calculi. Report of a case and study of five normal subjects. New Engl. J. Med. 1957, 256, 1215.

9. Kuyper, A. C., and Mattill, H. A. Some aspects of citric acid metabolism. J. biol. Chem. 1933, 103, 51.

10. Milne, M. D., Scribner, B. H., and Crawford, M. A. Non-ionic diffusion and the excretion of weak acids and bases. Amer. J. Med. 1958, 24, 709.

11. Herrin, R. C., and Lardinois, C. C. Renal clearance of citric acid in the dog. Proc. Soc. exp. Biol. (N. Y.) 1958, 97, 294.

12. Grollman, A. P., Harrison, H. C., and Harrison, H. E. The renal excretion of citrate. J. clin. Invest. 1961, 40, 1290.

13. Gordon, E. E. The metabolism of citrate- $\mathrm{C}^{14}$ in normal and in fluoroinhibitor-poisoned rats. $\mathrm{J}$. clin. Invest. 1961, 40, 1719.

14. Stern, J. R. Assay of tricarboxylic acids in Methods in Enzymology, S. P. Colowick and N. O. Kaplan, Eds. New York, Academic Press, 1957, vol. 3, p. 425 .

15. Nordmann, R., Marty, A., Tholozan, A., and Nordmann, $J$. Détermination des acides organiques du plasma humain par chromatographie sur papier. C. R. Acad. Sci. (Paris) 1957, 245, 2414.

16. Hartley, R. D., and Lawson, G. J. Improved methods for the paper chromatography of organic acids. J. Chromatog. 1960, 4, 410.
17. Dickens, F. The citric acid content of animal tissues, with reference to its occurrence in bone and tumour. Biochem. J. 1941, 35, 1011.

18. Elliott, J. R., and Freeman, S. Parathyroid function and the plasma citric acid and calcium response to nephrectomy. Endocrinology 1956, 59, 181.

19. Mårtensson, J. On the citric acid metabolism in mammals. Acta physiol. scand. 1940, 1, suppl. 2, 1.

20. Herndon, R. F., and Freeman, S. Renal citric acid utilization in the dog. Amer. J. Physiol. 1958, 192, 369.

21. Grollman, A. P., Walker, W. G., Harrison, H. C., and Harrison, H. E. Localization of calcium and citrate reabsorption. Fed. Proc. 1962, 21, 436.

22. Crawford, M. A., Milne, M. D., and Scribner, B. H. The effects of changes in acid-base balance on urinary citrate in the rat. J. Physiol. 1959, 149, 413.

23. Orten, J. M., and Smith, A. H. A study of certain metabolites and related compounds as precursors of endogenous citric acid. J. biol. Chem. 1937, 117, 555.

24. Crawford, M. A., and Milne, M. D. Renal-tissue citrate and citrate excretion in the rat. Biochem. J. 1960, 76, 23 P.

25. Craig, J. W., Miller, M., Owens, J. E., and Woodward, H., Jr. Renal malic acid metabolism in vivo. Fed. Proc. 1953, 12, 29.

26. Vishwakarma, P., and Lotspeich, W. D. The excretion of $l$-malic acid in relation to the tricarboxylic acid cycle in the kidney. J. clin. Invest. 1959, 38, 414.

27. Gordon, E. E. Unpublished observations.

\section{ANNOUNCEMENT OF MEETINGS}

THE AMERICAN FEDERATION FOR CLINICAL RESEARCH will hold its Twentieth Annual Meeting in Atlantic City, N. J., at the Casino Theatre on the Steel Pier on Sunday, April 28, 1963, at 9:00 a.m. Joint sectional meetings with The American Society for Clinical Investigation will be held on Sunday afternoon at Chalfonte-Haddon Hall, and additional meetings sponsored by The American Federation for Clinical Research will be held there on Sunday evening.

THE AMERICAN SOCIETY FOR CLINICAL INVESTIGATION, INC., will hold its Fifty-fifth Annual Meeting in Atlantic City, N. J., on Monday, April 29, at 9:00 a.m., at the Casino Theatre on the Steel Pier and in simultaneous programs sponsored with The American Federation for Clinical Research on Sunday afternoon, April 28, in Chalfonte-Haddon Hall.

THE ASSOCIATION OF AMERICAN PHYSICIANS will hold its Seventy-sixth Annual Meeting in Atlantic City, N. J., at the Casino Theatre on the Steel Pier on Tuesday, April 30, at 9:30 a.m., and in the Vernon Room, Chalfonte-Haddon Hall, on Wednesday, May 1, at 9:30 a.m. 